\title{
On the trophic coupling between protists and copepods in arctic marine ecosystems
}

\author{
Henrik Levinsen $^{1, *}{ }^{\text {, Jefferson T. Turner }}{ }^{2}$, Torkel G. Nielsen ${ }^{1}$, Benni W. Hansen ${ }^{3}$ \\ ${ }^{1}$ National Environmental Research Institute, Department of Marine Ecology, Frederiksborgvej 399, PO Box 358, \\ 4000 Roskilde, Denmark \\ ${ }^{2}$ University of Massachusetts Dartmouth, Center for Marine Science and Technology, \\ 706 South Rodney French Boulevard, New Bedford, Massachusetts 02744, USA \\ ${ }^{3}$ Roskilde University, Department of Life Sciences and Chemistry, PO Box 260, 4000 Roskilde, Denmark
}

\begin{abstract}
Grazing experiments were conducted at different seasons with the large Calanus finmarchicus, C. glacialis and C. hyperboreus, and the small Acartia longiremis in Disko Bay, West Greenland and Young Sound, NE Greenland. Female copepods incubated in $200 \mu \mathrm{m}$ screened natural water preferred large protists. Thus, particularly during the post-bloom period, the relatively large heterotrophic protists (ciliates and heterotrophic dinoflagellates) contributed substantially to the trophic coupling between protists and copepods. However, low grazing by C. glacialis and $C$. hyperboreus in mid-June suggests that large parts of the populations of these species had terminated feeding at this time, prior to overwintering. Clearance increased with ciliate and dinoflagellate size above $10 \mu \mathrm{m}$ equivalent spherical diameter (ESD), equal to the size of the smallest heterotrophic protists. At a size of 30 to $40 \mu \mathrm{m}$ ESD maximum clearance was observed. Grazing on Phaeocystis single cells of $5 \mu \mathrm{m}$ by $C$. finmarchicus showed a lower size-limit for capture of this species $<5 \mu \mathrm{m}$ which contrasts with $C$. glacialis and $C$. hyperboreus, which had a lower size-limit near $10 \mu \mathrm{m}$. In addition to size and relative concentrations of phytoplankton and heterotrophic protists, prey and/or predator behavior is suggested to play an important role for copepod feeding.
\end{abstract}

KEY WORDS: Calanus spp. A Acartia longiremis · Omnivory · Ciliates · Heterotrophic dinoflagellates · Trophic coupling $\cdot$ Particle spectra $\cdot$ Plankton food web $\cdot$ Arctic

Resale or republication not permitted without written consent of the publisher

\section{INTRODUCTION}

Most arctic marine research on the fate of pelagic primary production has taken herbivory by the abundant northern copepods Calanus finmarchicus, $C$. glacialis and C. hyperboreus into consideration (e.g. Conover \& Huntley 1991, Conover et al. 1991). It is often assumed that the food source of these copepods consists almost entirely of phytoplankton. Accordingly, the trophic coupling between Calanus spp. and protists such as ciliates and heterotrophic dinoflagellates has been less thoroughly examined. An increasing number of studies have stressed, however, that ciliates

*E-mail: hle@dmu.dk are also abundant in marine pelagic food webs at high northern latitudes. This was first shown in a study from the Chucki Sea/Bering Strait by Andersen (1988) who demonstrated the importance of the 'microbial loop' at stations dominated by small-sized phytoplankton. A few subsequent studies have also suggested that heterotrophic dinoflagellates are important grazers, along with ciliates and copepods (Nielsen \& Hansen 1995, Levinsen et al. 1999). This prompted a comparison of the grazing impact of different grazers. Based on biomass considerations and measurements of growth it was concluded that ciliates and heterotrophic dinoflagellates were potentially more important for the carbon flow in the Arctic than copepods during the late summer (Hansen et al. 1999). Heterotrophic dinofla- 
gellates contributed more than half of the heterotrophic protist biomass and, like copepods, were potentially important grazers of diatoms. However, it was unknown how much the heterotrophic protists contributed to the copepod diet. Thus, although heterotrophic protists were likely important for the carbon flow, knowledge about how much primary production enters higher trophic levels through heterotrophic protists in cold-water systems was generally lacking. Thus far, apparently, only a single such study from the Greenland Sea has been conducted, from which it was concluded that ciliates were indeed important food for Calanus spp. (Barthel 1988). There is a need for more information about the trophic coupling between copepods and heterotrophic protists, including the important heterotrophic dinoflagellates, if the fate of the primary production in arctic areas is to be fully understood.

Relatively large heterotrophic protists are abundant in the low-chlorophyll a surface water of stratified arctic ecosystems after the main spring/summer bloom of diatoms (Levinsen et al. 1999, 2000). During this period small-sized phytoplankton closer to the lower limit of capture by copepods dominate. In post-bloom surface waters heterotrophic protists are therefore more exposed to copepods than phytoplankton, which are presumed to be less efficiently retained. At the pycnocline, in contrast, subsurface diatom blooms composed of larger cells at high concentrations are usually characteristic post-bloom features (Nielsen \& Hansen 1999). There is a need to elucidate possible differences in the coupling between heterotrophic protists and copepods under these contrasting situations.

Knowledge of copepod predation on ciliates and heterotrophic dinoflagellates based on field experiments is also pivotal if the seasonal dynamics of the heterotrophic protists are to be understood. The capability of copepods to regulate ciliates, heterotrophic dinoflagellates and other large heterotrophic protists is often interpreted as the main reason for the relative constancy of their abundance in the sea despite a high growth potential (cf. Kiørboe 1998). Compared to other trophic interactions in the planktonic food web (e.g. bacteria-heterotrophic nanoflagellates), few studies have measured ingestion of ciliates and heterotrophic dinoflagellates by copepods. Regulation has most often been suggested indirectly from predator-prey population dynamics (Smetacek 1981, Nielsen \& Kiørboe 1994).

Populations of small-bodied copepods are often ignored in Calanus-dominated systems because plankton net with coarse mesh size is traditionally used for sampling. In contrast to Calanus spp. small copepods usually remain in the upper water layers, so when Calanus spp. descend to the bottom water to over- winter, small-bodied copepods like Acartia longiremis become dominant (Hansen et al. 1999). The importance of these copepods in the trophic coupling is unknown.

This paper presents results from a series of copepod grazing experiments with females of Calanus finmarchicus, C. glacialis, C. hyperboreus and Acartia longiremis conducted in Disko Bay, West Greenland and Young Sound, NE Greenland at different seasons. The goals were (1) to compare copepod clearance and ingestion on ciliates, heterotrophic dinoflagellates and phytoplankton in bloom and post-bloom situations, respectively and (2) to generate an average weightspecific clearance on heterotrophic protists, which could be applied in arctic food web models.

\section{METHODS}

Experiments were conducted in Disko Bay, West Greenland aboard the RV 'Adolf Jensen' (Greenland Institute for Natural Resources) or the RV 'Porsild' (Copenhagen University) in June 1997, April and August 1998. An additional experiment was conducted in the ice-covered Young Sound, NE Greenland in June 1999 (Fig. 1).

Copepods were collected from the upper $30 \mathrm{~m}$ of the water column using a $200 \mu \mathrm{m}$ mesh size WP-2 net fitted with a large non-filtering cod-end. Within $\sim 3 \mathrm{~h}$ of collection individual female Calanus spp. or Acartia longiremis were transferred to 2.33 or $2.77 \mathrm{l}$ acid-washed polycarbonate bottles with $200 \mu \mathrm{m}$ pre-filtered water. Water for incubation was collected from $2.5 \mathrm{~m}$ or the depth of chlorophyll maximum using a 101 Niskin bottle. The time of incubation varied between 20 and $40 \mathrm{~h}$ depending on species and number of female copepods added to each grazing bottle (Table 1). Bottles were incubated at in situ temperature in a container with flow-through surface water and rotated intermittently by hand throughout the experiments. Initial bottles were immediately preserved with acid Lugol's to a final concentration of $2 \%$. At the end of the incubations, controls (without animals) and grazing bottles (added copepods) were preserved and the condition of the females (dead or alive) was recorded. Subsamples for determination of chl a were also taken; $200 \mathrm{ml}$ aliquots were filtered through GF/F filters and darkextracted in ethanol before measurement on a Turner fluorometer (Jespersen \& Christoffersen 1987).

Phytoplankton in preserved aliquots were concentrated by sedimentation and larger phytoplankton cells counted at 100 or $200 \times$, smaller cells at 200 or $400 \times$, in Sedgwick Rafter cells with conventional phasecontrast microscopy utilizing long-working-distance objectives. Ciliates and dinoflagellates were concen- 


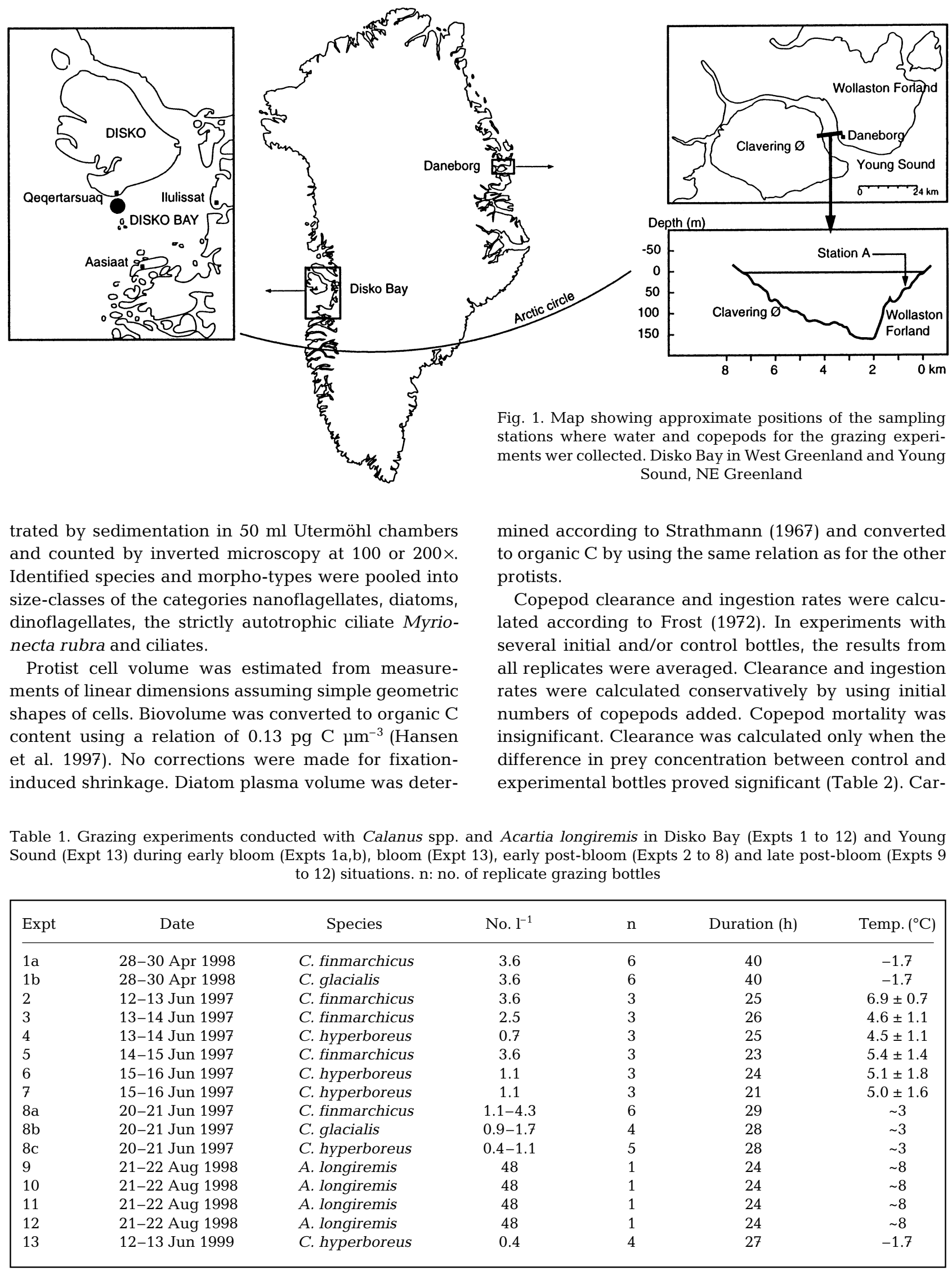


Table 2. Significance levels for the differences between prey densities in control and grazing bottles $\left(t\right.$-test). ${ }^{* * * *} p<0.01,{ }^{* * *} p<$ $0.05,{ }^{* *} \mathrm{p}<0.10,{ }^{*} \mathrm{p}<0.20$, ns: no significant difference. -: no data. Calanus finmarchicus (C. fin), C. glacialis (C. gla), C. hyperboreus (C. hyp)

\begin{tabular}{|c|c|c|c|c|c|c|c|c|c|}
\hline \multirow[t]{2}{*}{ Expt } & \multirow[t]{2}{*}{ Species } & \multicolumn{4}{|c|}{ Ciliates } & \multicolumn{3}{|c|}{ Dinoflagellates } & \multirow{2}{*}{$\begin{array}{l}\text { Chl a } \\
\text { Total }\end{array}$} \\
\hline & & Total & $<20 \mu \mathrm{m}$ & $>20 \mu \mathrm{m}$ & Myrionecta & Total & $>20 \mu \mathrm{m}$ & $<20 \mu \mathrm{m}$ & \\
\hline $1 \mathrm{a}$ & C. fin & $* * * *$ & $* * * *$ & - & - & $\mathrm{ns}$ & $* * *$ & ns & $* * * *$ \\
\hline $1 b$ & C. gla & $* * * *$ & $* * * *$ & - & - & ns & $* * * *$ & ns & $* * * *$ \\
\hline 2 & C. fin & $* * *$ & $* *$ & $* * * *$ & - & $\mathrm{ns}$ & $* *$ & ns & - \\
\hline 3 & C. fin & $* * *$ & $* * *$ & $* * *$ & * & $* *$ & $* *$ & $*$ & - \\
\hline 4 & C. hyp & $\mathrm{ns}$ & $\mathrm{ns}$ & ns & - & ns & ns & $\mathrm{ns}$ & - \\
\hline 5 & C. fin & $* * *$ & $*$ & ${ }^{* *}$ & $* * *$ & $* * *$ & $* *$ & $* * *$ & - \\
\hline 6 & C. hyp & ns & ns & ns & ns & ns & ns & $*$ & - \\
\hline 7 & C. hyp & $\mathrm{ns}$ & ns & ns & ns & ns & ns & $\mathrm{ns}$ & - \\
\hline $8 a$ & C. fin & $* * * *$ & $* * *$ & $* * * *$ & $* * * *$ & $* * * *$ & $* * * *$ & $* * * *$ & $* * * *$ \\
\hline $8 b$ & C. gla & ns & ns & ns & ns & ns & * & ns & ns \\
\hline $8 \mathrm{c}$ & C. hyp & $* *$ & $* *$ & * & ns & * & $* * *$ & ns & ns \\
\hline 13 & C. hyp & $* * * *$ & $* *$ & $* * *$ & ns & _- & $* * *$ & - & $* *$ \\
\hline
\end{tabular}

bon ingestion was obtained from the product of the number of cells ingested and the weighted mean $\mathrm{C}$ content for that cell category in the initial bottles. The mean cell $\mathrm{C}$ content for each cell category was obtained by weighting the $\mathrm{C}$ content for each species by its relative abundance. The weight-specific clearance $\left(\mathrm{ml} \mu \mathrm{g}^{-1} \mathrm{C}^{-1} \mathrm{~d}^{-1}\right)$ and ingestion $\left(\mu \mathrm{g} \mathrm{C} \mu \mathrm{g}^{-1} \mathrm{C} \mathrm{l}^{-1}\right.$ $\mathrm{d}^{-1}$ ) rates were estimated using the mean female carbon weight of the respective copepod species in Disko Bay (Table 3). A $Q_{10}=2.8$ was used to eliminate temperature differences among the experiments (Hansen et al. 1997).

The total carbon ingestion of Acartia longiremis was calculated based on egg production measurements assuming a gross egg production efficiency of $33 \%$. Egg production was converted to carbon from egg volume and a relation of $0.14 \mathrm{pg} \mathrm{C} \mathrm{m}^{-3}$ (Kiørboe et al. 1985).

In the following sections, we refer to bloom and postbloom grazing experiments, respectively, based on the physical structure of the water column and the distribution of phytoplankton at the time of sampling.

\section{RESULTS}

The grazing experiments were conducted at temperatures covering the seasonal cycle observed in Disko

Table 3. Calanus spp. mean \pm SE of the female cephalothorax length and carbon weight (from S. D. Madsen, T. G. Nielsen \& B. W. Hansen unpubl.)

\begin{tabular}{|c|c|c|c|}
\hline & finmarchicus & C. glacialis & C. hyperboreus \\
\hline Length $(\mu \mathrm{m})$ & $2680 \pm 60$ & $3460 \pm 100$ & $6450 \pm 260$ \\
\hline Weight $(\mu \mathrm{g} C)$ & ) $160 \pm 10$ & $410 \pm 50$ & $940 \pm 120$ \\
\hline
\end{tabular}

Bay and Young Sound $\left(-1.7\right.$ to $\left.8^{\circ} \mathrm{C}\right)$, and contained phytoplankton and heterotrophic protist assemblages with abundances typical for spring and summer (Fig. 2). Initial chl a concentrations were between 0.2 and $8.6 \mu \mathrm{g} \mathrm{l}^{-1}$. These were highest in April during the early spring bloom and in June at the depth of the subsurface maximum, and lowest in surface water in June (Fig. 2a,b). Cells $>10 \mu \mathrm{m}$ usually dominated the phytoplankton, although cells $<10 \mu \mathrm{m}$ contributed substantially. The ciliate and dinoflagellate biomass varied from $\sim 1$ to $20 \mu \mathrm{g} \mathrm{Cl}^{-1}$ (Fig. 2c,d). By applying a carbonchlorophyll a ratio of 50 it was estimated that ciliates and dinoflagellates on average constituted $5 \%$ of total protist carbon during the spring bloom and at the subsurface chlorophyll a peak, whereas they constituted more $(34 \%)$ in the surface water. Naked oligotrich ciliates and athecate gymnodinoid dinoflagellates were most abundant. Heterotrophic and autotrophic dinoflagellates were not separated in this study, but it is assumed here that heterotrophic species constituted the majority of the dinoflagellates, in agreement with previous studies from the area (Levinsen et al. 1999, 2000).

\section{Clearance}

Grazing of protists differed between Calanus spp. with the largest species performing the highest clearance (Fig. 3). A difference in their seasonal grazing patterns was also observed. Clearance by Calanus finmarchicus was highest during the warmer post-bloom period. Here, a rate of $\sim 500 \mathrm{ml}$ female $^{-1} \mathrm{~d}^{-1}$ on the autotrophic ciliate Myrionecta rubra and oligotrichous ciliates $>20 \mu \mathrm{m}$ was measured (Fig. 3a,b). Lower clearances were found on chl $a$ and oligotrichs $<20 \mu \mathrm{m}$ (306 and $271 \mathrm{ml}$ female $\mathrm{e}^{-1} \mathrm{~d}^{-1}$, respectively). Dinoflagellates 

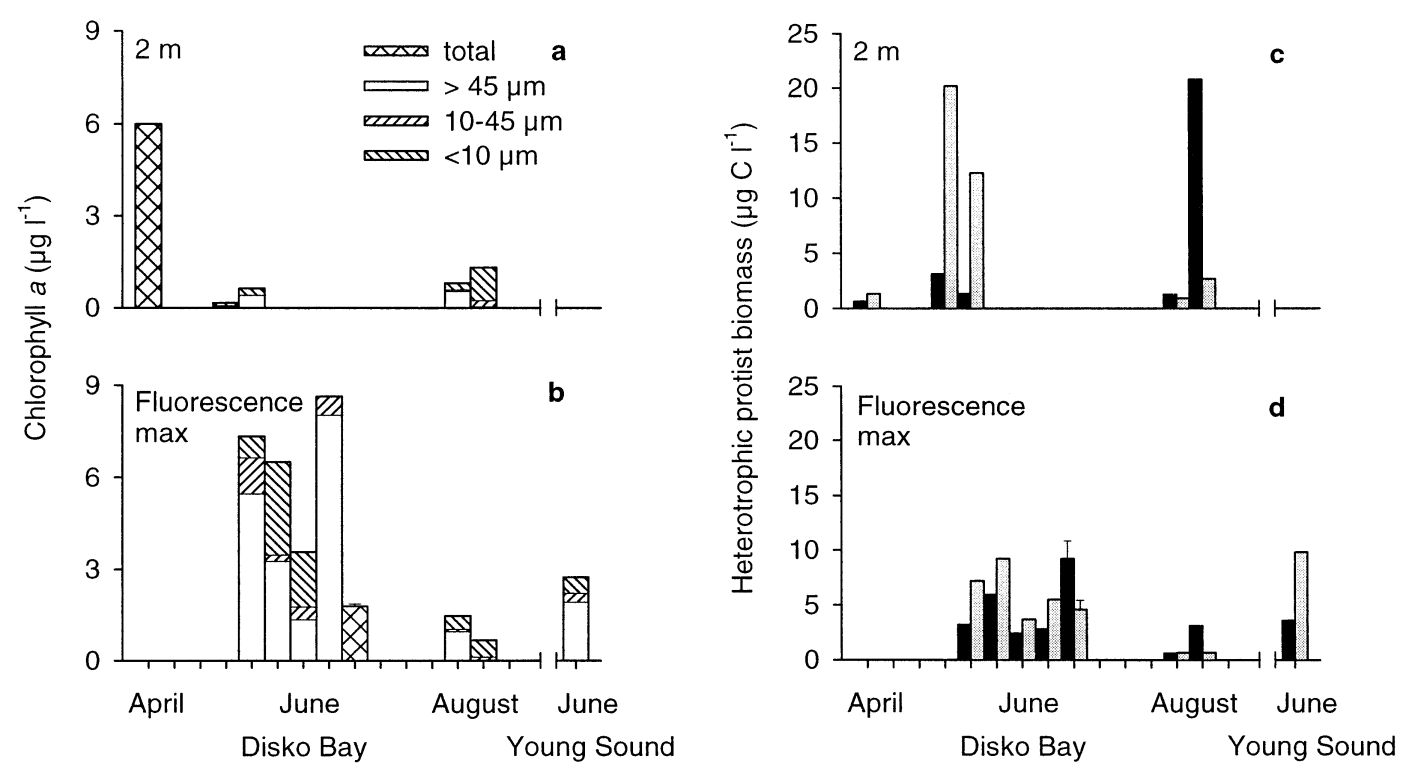

Fig. 2. Initial concentrations of total and size-fractionated phytoplankton expressed as chl $a(\mathrm{a}, \mathrm{b})$ and biomasses of ciliates (black) and dinoflagellates (grey) (c,d) in experimental water collected from $2 \mathrm{~m}$ and the depth of the fluorescence maximum (usually $~ 30 \mathrm{~m}$ )
Bloom $\left(-1.7^{\circ} \mathrm{C}\right)$
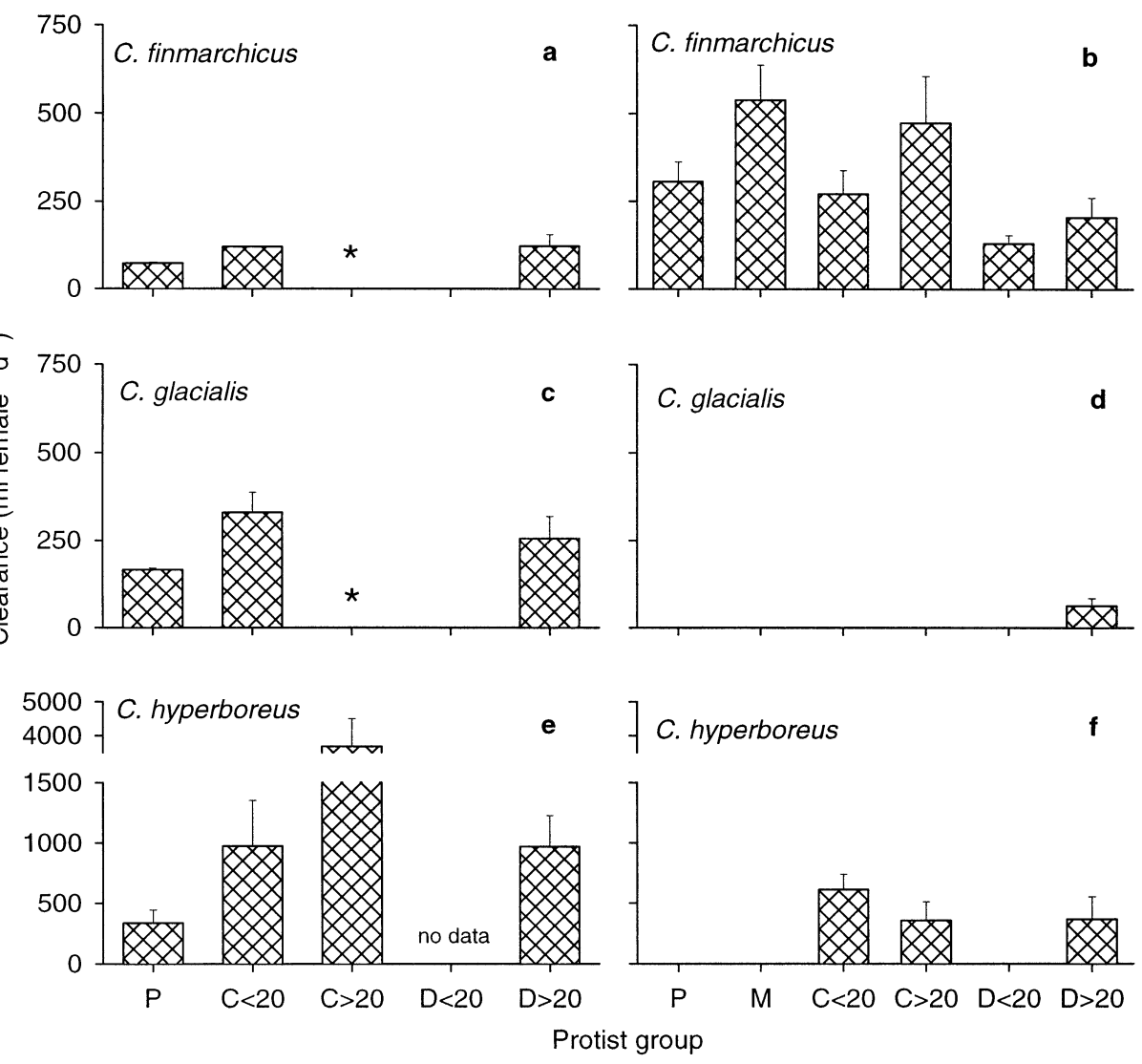

Post bloom $\left(3^{\circ} \mathrm{C}\right)$

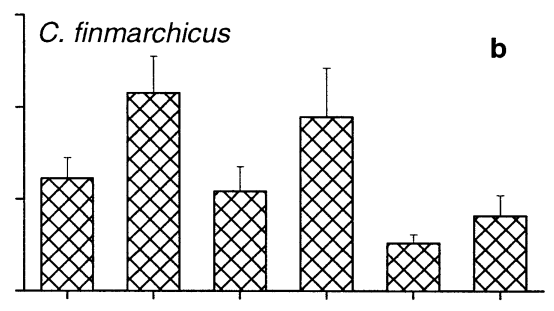

C. glacialis $\quad$ d

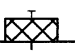

(1)

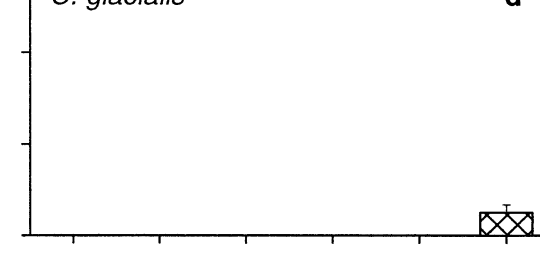

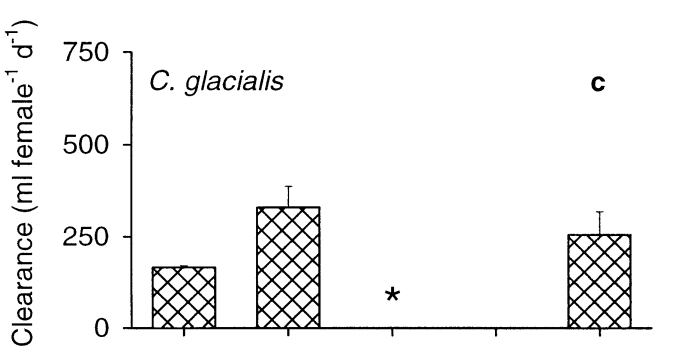

Sound
nes (black) and
(usually $\sim 30 \mathrm{~m}$ )

Fig. 3. Bloom and post-bloom clearance by Calanus spp. on chl a (P), Myrionecta rubra (M), and oligotrichous ciliates (C) and dinoflagellates (D) with ESD $<20 \mu \mathrm{m}$ and $>20 \mu \mathrm{m}$. Experiments were initiated on 28 April $(\mathrm{a}, \mathrm{c}), 12$ June (e), and 20 June (b,d,f). Initial chl a concentrations on these dates were 6.0,2.7 and $1.8 \mu \mathrm{g} \mathrm{l}^{-1}$, respectively. For further information on experimental conditions, see Table 1 . Error bars indicate $\pm \mathrm{SE}$ of the mean (too small to be seen in a and c). ${ }^{*}$ Concentrations of ciliates $>20 \mu \mathrm{m}$ ESD in these experiments were too low to allow calculation of clearance 
were grazed least efficiently, particularly cells $<20 \mu \mathrm{m}$. In contrast, grazing by C. glacialis and C. hyperboreus was low or undetectable during the post-bloom period compared to the bloom period (Fig. 3c-f). Grazing was consistently lower although the temperature had increased by $5^{\circ} \mathrm{C}$. Calanus glacialis only cleared dinoflagellates $>20 \mu \mathrm{m}$ while $C$. hyperboreus also cleared ciliates at relatively low rates. Grazing of heterotrophic protists by $C$. hyperboreus was not detected in any other post-bloom incubations (Expts 4, 6, 7; Table 2). When grazing was measured, $C$. glacialis and $C$. hyperboreus, like $C$. finmarchicus, cleared ciliates at a significantly greater rate than they cleared chl $a$. The clearance of ciliates was $\sim 300$ and 1000 to $3700 \mathrm{ml}$ female $\mathrm{e}^{-1} \mathrm{~d}^{-1}$ for $C$. glacialis and C. hyperboreus, respectively. Corresponding values for clearance on chl $a$ were 166 and $338 \mathrm{ml}$ female ${ }^{-1} \mathrm{~d}^{-1}$ (Fig. 3c,e). All 3 species of Calanus generally did not graze on dinoflagellates $<20 \mu \mathrm{m}$ (Table 2).

Cell counts supported the clearance results from chl a measurements in that there was more grazing on phytoplankton by Calanus finmarchicus than by $C$. glacialis and C. hyperboreus during the post-bloom period. C. finmarchicus grazed on all major protist groups including Myrionecta rubra and nanoflagellates dominated by solitary Phaeocystis cells $\sim 5 \mu \mathrm{m}$ in size (Fig. 4). In contrast, there was no or only low grazing on phytoplankton by $C$. glacialis and C. hyperboreus (Tables $4 \& 5$ ). Low grazing on nanoflagellates during the post-bloom period was observed only once by C. hyperboreus (Expt 4). Generally, C. glacialis cleared diatoms, while $C$. hyperboreus did not and neither species cleared nanoflagellates. In fact, the nanoflagellate abundance increased significantly compared to controls during incubations with added $C$. hyperboreus (Table 5).
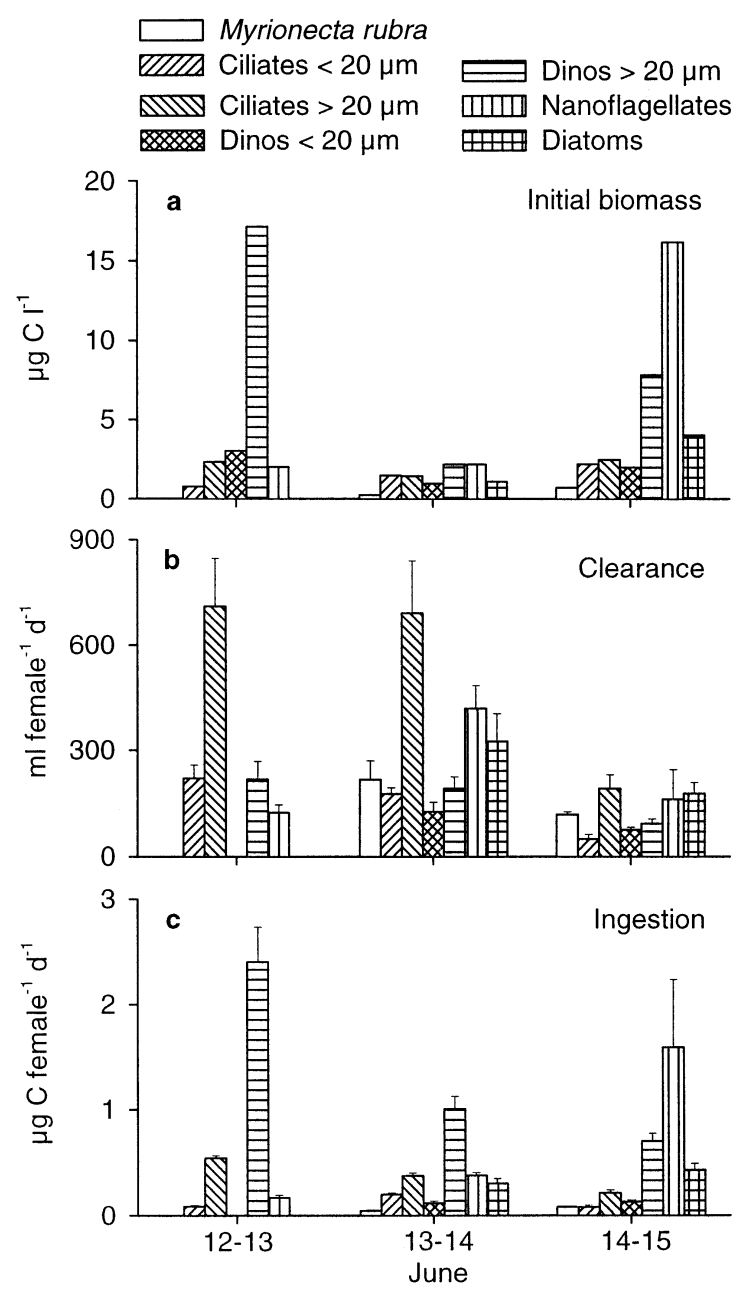

Fig. 4. Calanus finmarchicus. Post-bloom (a) initial biomass, (b) clearance and (c) ingestion of major protist groups in 3 grazing experiments performed with surface water $(12-13$ June) and water from the depth of the fluorescence maximum (13-15 June). Error bars indicate \pm SE of the mean

Table 4. Post-bloom grazing of major phytoplankton groups in Disko Bay (12-16 June). Concentration in initial (Init), control (Con) and grazing bottles with added Calanus finmarchicus (C. fin) or C. hyperboreus (C. hyp). No. of replicates is given after bottle name. SE is given in parentheses. Significance levels of the difference between control and experimental prey densities as explained in Table 2

\begin{tabular}{|c|c|c|c|c|c|c|}
\hline \multirow[t]{2}{*}{ Expt } & \multirow{2}{*}{$\begin{array}{l}\text { Copepod } \\
\text { species }\end{array}$} & \multirow{2}{*}{$\begin{array}{l}\text { Phytoplankton } \\
\text { group }\end{array}$} & \multicolumn{3}{|c|}{ Concentration (cells $\times 10^{3} \mathrm{l}^{-1}$ ) } & \multirow[t]{2}{*}{$\mathrm{p}$} \\
\hline & & & Init, 1 & Con, 1 & Grazing, 3 & \\
\hline \multirow[t]{2}{*}{2} & \multirow[t]{2}{*}{ C. fin } & Nanoflagellates & 31 & 22 & 14 & $* *$ \\
\hline & & Diatoms & 0 & 1 & $0 \quad(0)$ & $*$ \\
\hline \multirow[t]{2}{*}{3} & \multirow[t]{2}{*}{ C. fin } & Nanoflagellates & 18 & 34 & 11 & $* * *$ \\
\hline & & Diatoms & 7 & 14 & 6 (1) & $* *$ \\
\hline \multirow[t]{2}{*}{4} & \multirow[t]{2}{*}{ C. hyp } & Nanoflagellates & 5 & 4 & $3(0)$ & $*$ \\
\hline & & Diatoms & 6 & 5 & 4 (1) & $*$ \\
\hline \multirow[t]{2}{*}{5} & \multirow[t]{2}{*}{ C. fin } & Nanoflagellates & 250 & 192 & $119(29)$ & $* * *$ \\
\hline & & Diatoms & 27 & 17 & 9 (1) & ** \\
\hline \multirow[t]{2}{*}{6} & \multirow[t]{2}{*}{ C. hyp } & Nanoflagellates & 326 & 262 & $358(34)$ & ns \\
\hline & & Diatoms & 24 & 9 & $4 \quad(2)$ & ns \\
\hline \multirow[t]{2}{*}{7} & \multirow[t]{2}{*}{ C. hyp } & Nanoflagellates & 98 & 100 & $138(26)$ & ns \\
\hline & & Diatoms & 48 & 148 & $125(16)$ & $\mathrm{ns}$ \\
\hline
\end{tabular}


Table 5. Phytoplankton post-bloom grazing on 20-21 June in Disko Bay (Expt 8a-c). Concentration in initial (Init), control (Con) and grazing bottles with added Calanus finmarchicus (C. fin), C. glacialis (C. gla) or C. hyperboreus (C. hyp). SE is given in parentheses. No. of replicates is given after bottle name. Significance levels of the difference between control and experimental prey densities as explained in Table 2. neg: negative significant relationship

\begin{tabular}{|c|c|c|c|c|c|c|c|c|}
\hline \multirow[t]{2}{*}{ Species } & \multicolumn{5}{|c|}{ - Concentration (cells $\times 10^{3} \mathrm{l}^{-1}$ ) } & \multirow[b]{2}{*}{ C. fin } & \multirow{2}{*}{$\begin{array}{l}\text { Grazing } \\
\text { C. gla }\end{array}$} & \multirow[b]{2}{*}{ C. hyp } \\
\hline & Init, 3 & Con, 7 & C. fin, 6 & C. gla, 4 & C.hyp, 5 & & & \\
\hline Nitzschia spp. & $\begin{array}{l}43 \\
(7)\end{array}$ & $\begin{array}{c}2 \\
(0)\end{array}$ & $\begin{array}{c}1 \\
(0)\end{array}$ & $\begin{array}{c}1 \\
(1)\end{array}$ & $\begin{array}{c}2 \\
(1)\end{array}$ & * & ns & ns \\
\hline Thalassiosira spp. & $\begin{array}{l}17 \\
(7)\end{array}$ & $\begin{array}{l}16 \\
(5)\end{array}$ & $\begin{array}{c}7 \\
(2)\end{array}$ & $\begin{array}{c}6 \\
(3)\end{array}$ & $\begin{array}{l}15 \\
(4)\end{array}$ & * & * & ns \\
\hline Chaetoceros spp. & $\begin{array}{l}14 \\
(5)\end{array}$ & $\begin{array}{c}8 \\
(2)\end{array}$ & $\begin{array}{c}7 \\
(2)\end{array}$ & $\begin{array}{c}4 \\
(1)\end{array}$ & $\begin{array}{c}7 \\
(2)\end{array}$ & ns & $*$ & ns \\
\hline Diatoms, total & $\begin{array}{c}74 \\
(14)\end{array}$ & $\begin{array}{l}25 \\
(5)\end{array}$ & $\begin{array}{l}14 \\
(3)\end{array}$ & $\begin{array}{l}11 \\
(2)\end{array}$ & $\begin{array}{l}24 \\
(6)\end{array}$ & ** & ** & ns \\
\hline Other & $\begin{array}{l}15 \\
(5)\end{array}$ & $\begin{array}{c}2 \\
(1)\end{array}$ & $\begin{array}{c}4 \\
(3)\end{array}$ & $\begin{array}{c}2 \\
(1)\end{array}$ & $\begin{array}{c}2 \\
(1)\end{array}$ & ns & ns & ns \\
\hline Nanoflagellates & $\begin{array}{l}13 \\
(2)\end{array}$ & $\begin{array}{c}69 \\
(21)\end{array}$ & $\begin{array}{c}34 \\
(12)\end{array}$ & $\begin{array}{c}62 \\
(58)\end{array}$ & $\begin{array}{l}143 \\
(44)\end{array}$ & ns & ns & ${ }^{*}($ neg $)$ \\
\hline $\begin{array}{l}\text { Phytoplankton, } \\
\text { total }\end{array}$ & $\begin{array}{l}101 \\
(20)\end{array}$ & $\begin{array}{l}95 \\
(22)\end{array}$ & $\begin{array}{c}56 \\
(12)\end{array}$ & $\begin{array}{c}76 \\
(59)\end{array}$ & $\begin{array}{l}169 \\
(50)\end{array}$ & ${ }^{* * *}$ & ns & ${ }^{*}($ neg $)$ \\
\hline
\end{tabular}

Weight-specific, temperature-corrected clearances revealed no significant difference between clearance of ciliates and dinoflagellates. The rates varied independently with heterotrophic protist concentration averaging ( $\pm \mathrm{SE}$ ) $1.0 \pm 0.1 \mathrm{ml} \mathrm{gg}^{-1} \mathrm{C} \mathrm{d}^{-1}$ at $3^{\circ} \mathrm{C}$ (Fig. 5).

Size of prey cells had a major effect on clearance (Fig. 6). Calanus spp. grazed on all sizes of ciliates and dinoflagellates but grazing was low on the smallest cells. The clearance on $10 \mu \mathrm{m}$ ESD (equivalent spherical diameter)-sized ciliates indicate that this size is close to the lower limit for particle capture. Within a prey size range of 10 to $30 \mu \mathrm{m} \mathrm{ESD}$, the clearance of

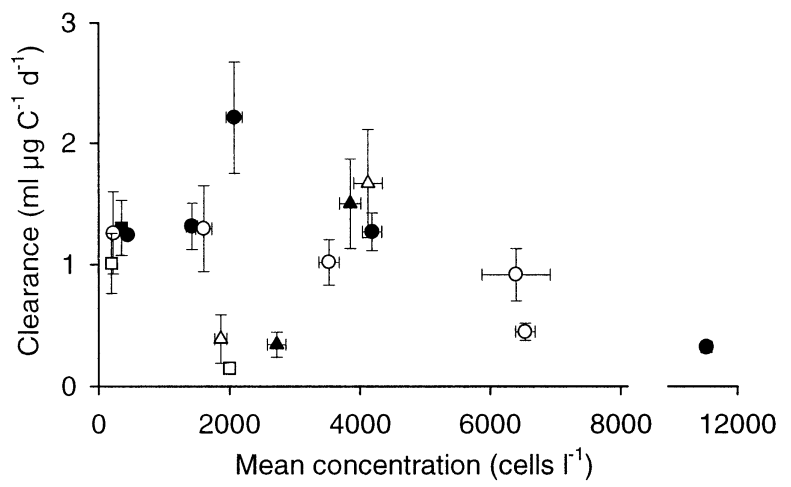

Fig. 5. Weight-specific clearance of ciliates (closed symbols) and dinoflagellates $>20 \mu \mathrm{m}$ (open symbols) by Calanus fin-

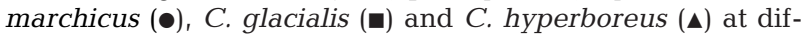
ferent concentrations of ciliates and dinoflagellates. Data were corrected to $3^{\circ} \mathrm{C}$ by using a $Q_{10}$ of 2.8 . Error bars indicate $\pm \mathrm{SE}$ of the mean ciliates and dinoflagellates by $C$. finmarchicus and $C$. hyperboreus increased from about 0 to $2-3 \mathrm{ml} \mathrm{g}^{-1} \mathrm{C}$ $\mathrm{d}^{-1}$. For prey $>25$ to $30 \mu \mathrm{m}$ ESD clearance was more variable (Fig. 6). Feeding rates were generally higher upon ciliates compared to upon similar-sized dinoflagellates. The range in heterotrophic protist cell size was too small in the experiments using C. glacialis to make a similar plot for this species, but they tended to follow the same pattern. Thus, ciliates with a mean size of $26 \mu \mathrm{m}$ ESD were grazed with a rate of $0.9 \mathrm{ml}_{\mu \mathrm{g}^{-1} \mathrm{C}}$ $\mathrm{d}^{-1}$ while the corresponding rate for $17 \mu \mathrm{m}$ ESD-sized dinoflagellates was 0.3 .

The functional response of Acartia longiremis grazing on natural populations of heterotrophic protists demonstrated a maximum weight-specific clearance for ciliates of $\sim 15 \mathrm{ml} \mathrm{ug}^{-1} \mathrm{C} \mathrm{d}^{-1}$ at $8^{\circ} \mathrm{C}$ (Fig. 7). Decreasing clearances were measured with increasing prey concentrations, and at concentrations higher than about $10^{4} \mathrm{l}^{-1}$ no grazing could be detected.

\section{Ingestion}

Because of high phytoplankton biomass as determined from chl $a$, heterotrophic protists contributed less to ingestion during the 28 to 30 April bloom experiments although they were cleared by copepods at the highest rate (Fig. 8a,b). The heterotrophic protists, which consisted almost entirely of cells $<20 \mu \mathrm{m}$, contributed only $0.5 \%$ to the ingestion by Calanus finmarchicus and C. glacialis. A larger contribution (12\%) was observed for C. hyperboreus during the spring 


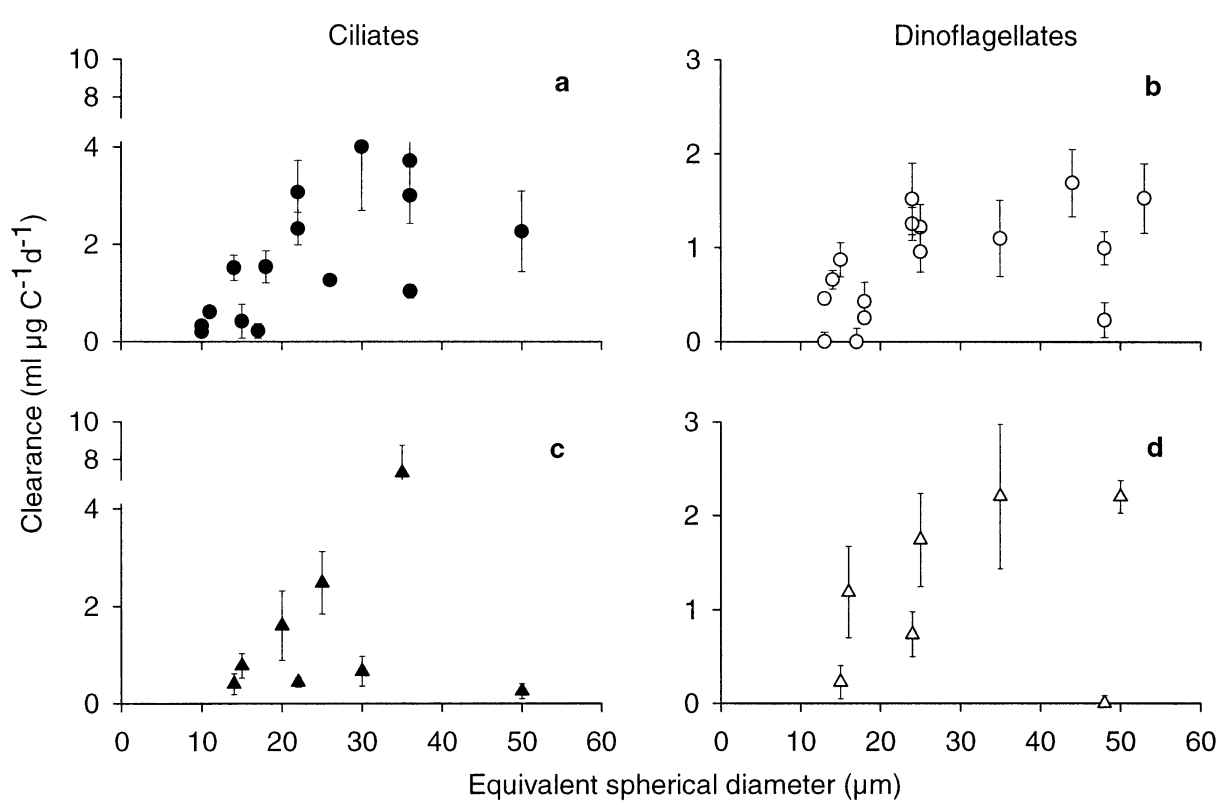

Fig. 6. Clearance by Calanus finmarchicus (upper panels) and C. hyperboreus (lower panels) on different cell sizes of (a,c) ciliates and $(b, d)$ dinoflagellates corrected to $3^{\circ} \mathrm{C}$. Cells within a size range have been pooled before calculation of the clearance.

Error bars indicate \pm SE of the mean

bloom in Young Sound where the concentration of chl a was lower (Fig. 8a,b). This latter value was similar to the post-bloom heterotrophic protist food share for C. finmarchicus in Disko Bay (Fig. 8c,d).

When the phytoplankton biomass was estimated from microscopic cell counts, the contribution of ciliates and dinoflagellates to total ingestion in postbloom experiments was larger. A particularly high

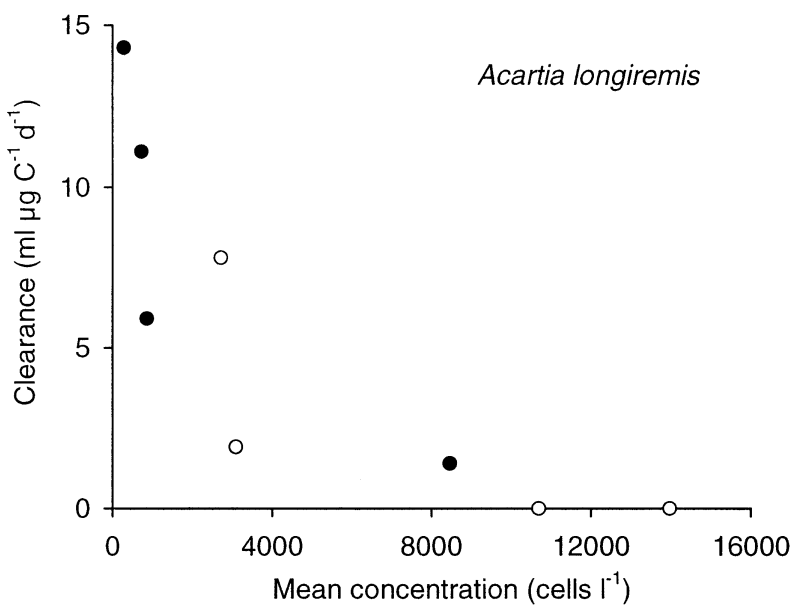

Fig. 7. Weight-specific clearance of ciliates $(\bullet)$ and dinoflagellates (O) by Acartia longiremis at different concentrations of ciliates and dinoflagellates. Weight of females was $3.7 \mu \mathrm{g} \mathrm{C}$ (from Hansen et al. 1999). Each point represents the mean female clearance at $8^{\circ} \mathrm{C}$ from a single grazing bottle share was observed in the low-chl a surface water on 12 and 13 June (Fig. 4). Here the ciliate and dinoflagellate proportions of total food were 20 and $75 \%$, respectively. In 2 other post-bloom grazing experiments, conducted during subsequent days with subsurface water, the heterotrophic protist shares were $72 \%$ (ciliates $25 \%$ ) and $37 \%$ (ciliates $11 \%$ ), respectively (Fig. 4c). During the post-bloom period, neither C. glacialis nor C. hyperboreus usually ingested phytoplankton, when measured as either chl $a$ or by cell counts, nor did they usually ingest heterotrophic protists. Ingestion of heterotrophic protists when occurring was positively related to their concentration (Fig. 9). Calanus spp. feeding increased when presented with more heterotrophic protists. The share of ciliates and dinoflagellates to the ingestion by Acartia longiremis in August as estimated from egg production was $<25$ and $<7 \%$ in August respectively (data not shown).

\section{DISCUSSION}

\section{Trophic coupling between protists and copepods}

In Disko Bay and Young Sound, ciliates and heterotrophic dinoflagellates are important grazers (Nielsen \& Hansen 1995, Levinsen et al. 1999, Rysgaard et al. 1999). The present study reveals that these heterotrophic protists can also constitute a substantial proportion of the copepod diet. The trophic coupling was 


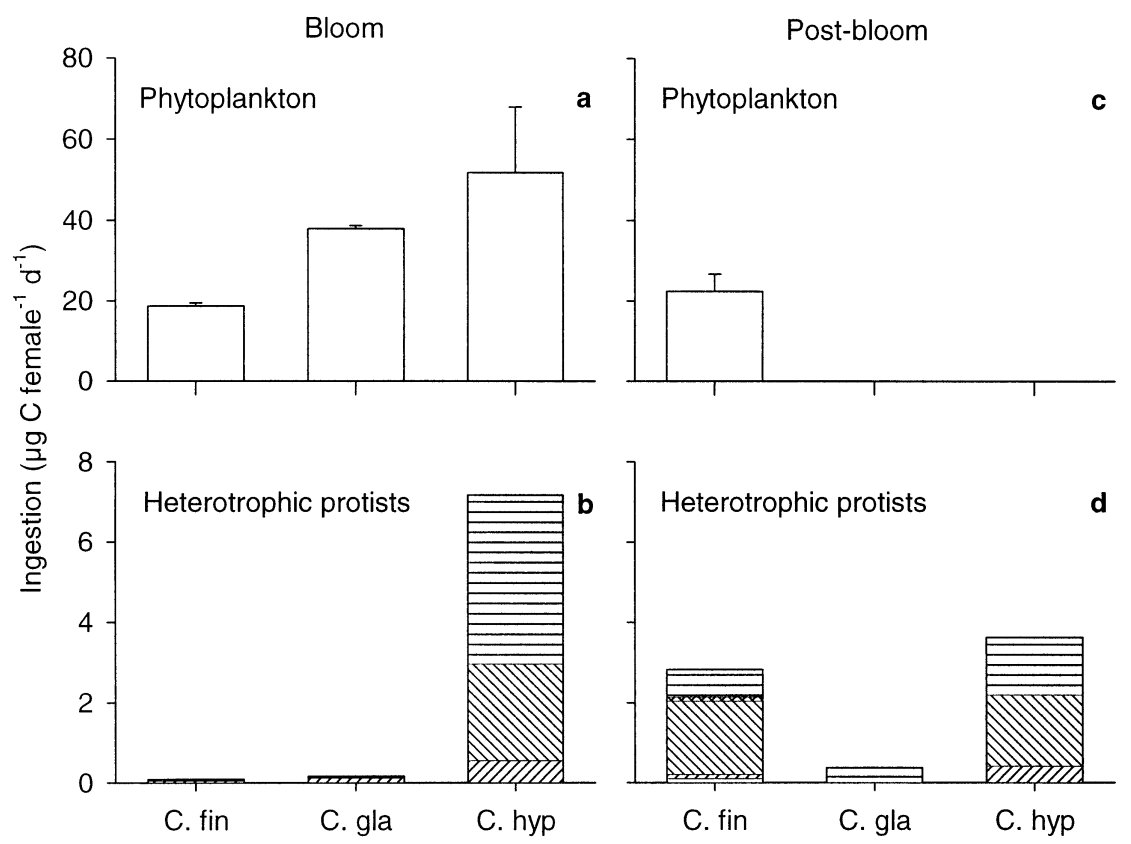

Fig. 8. Calanus spp. Bloom and post-bloom ingestion of $(\mathrm{a}, \mathrm{c})$ phytoplankton and $(\mathrm{b}, \mathrm{d})$ Myrionecta rubra, ciliates and dinoflagellates larger and smaller than $20 \mu \mathrm{m}$. Notice different scales on $y$-axis. Chl a was converted to phytoplankton carbon by using a relation of 1:50. Error bars indicate \pm SE of the mean (only upper panels). Same experiments as in Fig. 3 (key to identification of protist groups as in Fig. 4)

particularly strong during the post-bloom period, when heterotrophic protists may constitute the majority of total daily ingestion by Calanus finmarchicus (Fig. 4). Because heterotrophic protists likely had fed upon phytoplankton, in addition to small bacteria-eating flagellates, a large part of the primary production may therefore have reached the 'herbivorous' copepods via ciliates and heterotrophic dinoflagellates. The latter 2

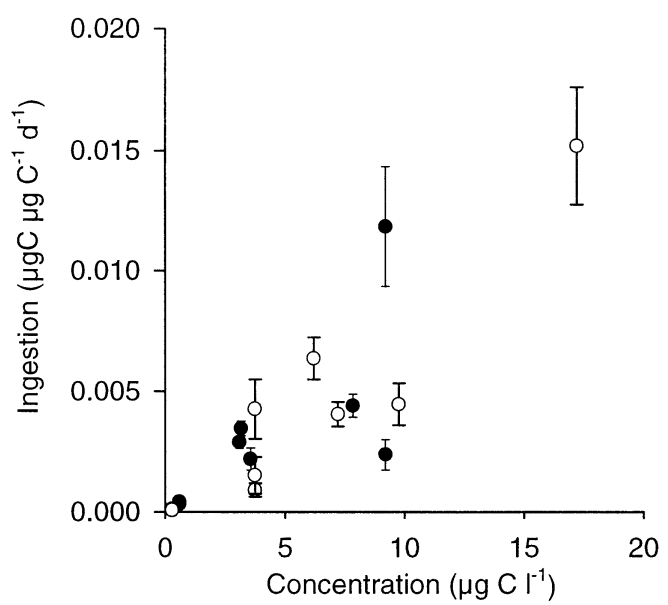

Fig. 9. Specific ingestion of ciliates $(\bullet)$ and dinoflagellates (o) at various heterotrophic protist concentrations in Disko Bay and Young Sound by Calanus spp. Data are not temperature corrected. Error bars indicate $\pm \mathrm{SE}$ of the mean groups thus provided a direct trophic linkage between phytoplankton and copepods.

The C-specific daily ration ( $\mu \mathrm{g} \mathrm{C}$ ingested $\mu \mathrm{g}^{-1}$ body $\mathrm{C} \mathrm{d}^{-1} \times 100$ ) for Calanus finmarchicus during the postbloom period was $\sim 2 \%$, close to daily rations of $1.1,1.8$ and $4.2 \%$ calculated from Ohman \& Runge (1994). These authors found such food rations sufficient to support fecundity, growth and development of C. finmarchicus in the Gulf of St. Lawrence. Assuming a similar role for heterotrophic protists in Disko Bay may have strong implications for the demography of the copepods because of the short season for growth. It can be speculated that heterotrophic protists influence the life history of the northern/arctic long-living Calanus spp. by extending the period for near-surface growth and development and postponing their descent to overwintering depths.

Conversely, during the early phases of the bloom, the contribution of ciliates to the diet of Calanus finmarchicus in Disko Bay was negligible ( 0.5\%). At this time, there was abundant phytoplankton and the copepods were predominantly herbivorous (Fig. 8). In the literature, a similar seasonal pattern related to the relative distribution of size and concentration of phytoplankton and heterotrophic protists has been reported for Acartia tonsa in the Gulf of Mexico (Gifford \& Dagg 1991).

For Calanus glacialis and C. hyperboreus the grazing pattern was different. The trophic coupling to heterotrophic protists might be important during spring, 
as demonstrated for C. hyperboreus in Young Sound, but these species usually did not graze during the postbloom period. In case they did, however, the food was often entirely composed of heterotrophic protists (Fig. 8). Thus, although grazing was sporadically measured and the rates were low compared to at bloom situations, they could contribute considerably to the coupling (Figs. $3 \& 8$ ). Large individual variability in gut fullness of Calanus spp. (up to a factor of 28) has previously been reported, even for copepods collected at the same time, locality and depth (Båmstedt 1988, Båmstedt et al. 1992). Variation in grazing activity between females was also indicated by the large standard errors of the feeding rates obtained in this study. Obviously, it is difficult to define the grazer activity of an 'average field individual' for these large copepod species. However, the observed seasonal variation, in addition to individual variability, probably reflects termination of feeding by part of the C. hyperboreus and C. glacialis populations prior to overwintering. This is supported by observations of empty (colorless) guts of post-bloom collected individuals.

The small-bodied Acartia longiremis also exhibited an omnivorous feeding strategy, which supports earlier suggestions from fatty acid analysis by Norrbin et al. (1990). If the observed high proportion of heterotrophic protists in the diet of $A$. longiremis is typical for this species, it could potentially sustain a trophic coupling and regulating impact on heterotrophic protists after the late stage Calanus spp. have descended to the bottom water in mid-summer.

The magnitude of the clearance by Acartia longiremis on heterotrophic protists can be evaluated by comparison with another report of their grazing on natural plankton. A. longiremis did not clear ciliates at detectable rates during an upwelling diatom bloom, but they cleared chl $a$ at a maximum of $16.8 \mathrm{ml} \mathrm{d}^{-1}$ at $10^{\circ} \mathrm{C}$ (Fessenden $\&$ Cowles 1994). This value is similar to $A$. longiremis clearance on ciliates measured in the present study.

\section{Understanding clearance in the field}

From the above it follows that the 'background level' of phytoplankton influences the importance of heterotrophic protists as vectors of primary production to higher trophic levels. Other factors that potentially influence clearance are prey concentration, prey size, and behavior of prey and predator.

\section{Concentration}

The functional response of Acartia longiremis (Fig. 7) was close to what would be expected if food concentration was the only variable, as has been shown in laboratory studies (e.g. Kiørboe et al. 1985). This indicates a fairly stable plankton composition between experiments using $A$. longiremis, a reasonable assumption because the experimental water was collected on the same day at positions close to each other. A rough comparison of heterotrophic protist size-classes confirms that the size compositions were actually quite similar. The functional response for Calanus spp. (Fig. 5) lacked such relation between clearance and concentration. It probably reflects that different plankton communities from different seasons and ecosystems were being compared. Thus, parameters in addition to the concentration of heterotrophic protists played an important role.

\section{Size}

Substantial clearance by Calanus finmarchicus on Phaeocystis solitary cells indicates that the size-limit for prey capture by this copepod was $<5 \mu \mathrm{m}$. In contrast, Phaeocystis was too small to be grazed by C. hyperboreus. Although grazer excretion can induce growth of small autotrophs leading to underestimates of their removal rates (Roman \& Rublee 1980), grazing by $C$. hyperboreus in this case did not occur. Thus, C. finmarchicus apparently was able to feed on smaller particles than C. hyperboreus. A difference in the lower size-limit of the particle-retention spectra between these 2 Calanus species is supported by results of Hansen et al. (1994). They found that C. finmarchicus CIV-V efficiently collected solitary Phaeocystis cells of $4.5 \mu \mathrm{m}$ in contrast to C. hyperboreus CV. Furthermore, Huntley (1981) found that female $C$. finmarchicus ingested particles in the 5 to $10 \mu \mathrm{m}$ particle category, while C. glacialis and C. hyperboreus did not.

Calanus spp. generally grazed ciliates more efficiently than phytoplankton. Large ciliates were cleared at a particularly high rate. Size-dependency is wellknown for copepods preying on phytoplankton (e.g. Frost 1972), but knowledge of size-dependent predation on heterotrophic protist prey is limited. Sizedependent clearance of heterotrophic protists has apparently been previously demonstrated only once for small-bodied neritic copepods preying on ciliates (Tiselius 1989). Our results, in agreement with that study, showed increasingly higher clearances with prey sizes above $\sim 10 \mu \mathrm{m}$ ESD, a size which corresponds to the smallest ciliates and dinoflagellates. Maximum capture efficiency for Calanus spp. was achieved for food with a size of approximately 30 to $40 \mu \mathrm{m}$ ESD. By comparison, Tiselius (1989) reported increasing clearances of ciliates by Acartia clusi until a size of $25 \mu \mathrm{m}$ ESD. Above this size, a fairly constant 
clearance was measured. In contrast, Tiselius found that clearance by Centropages hamatus increased continuously with size up to the largest size fraction offered, 35 to $50 \mu \mathrm{m}$ ESD ciliates. Frost (1972) also found a linear increase in clearance by Calanus pacificus with an increasing size of diatoms up to the largest tested diatom species of $67 \mu \mathrm{m}$ ESD.

\section{Behavior}

A continuous increase in clearance with size agrees with predicted filtration efficiencies from filtration of immobile prey until a critical size is reached, above which there is nearly $100 \%$ retention efficiency (Nival \& Nival 1976). However, increasing clearance with size might equally well imply that predator or prey behavior is also involved in the feeding process. On the one hand, large-sized prey emits stronger hydrodynamic signals, which should increase the capture efficiency by raptorial feeding copepods (Jonsson \& Tiselius 1990). On the other hand, if the copepods were suspension-feeding, the fact that relatively fastswimming ciliates were cleared with rates about twice as high as similar-sized slower-moving dinoflagellates (Fig. 6) may indicate that prey behavior influences the magnitude of the clearance by enhancing encounter rate. Whichever mechanism is the most important will be difficult to demonstrate with natural plankton assemblages, but should be addressed in future studies. It does not influence the conclusion of a sizedependent clearance, but it is in contrast to results of Tiselius (1989) who found that there was no difference between clearance on phytoplankton and ciliates when size was taken into account.

While small $(<20 \mu \mathrm{m}$ ESD) ciliates were grazed, clearance of small dinoflagellates was not detected for Calanus glacialis and C. hyperboreus. This was unexpected, based on assumptions of escape responses by ciliates similar to that demonstrated for Myrionecta rubra (Jonsson \& Tiselius 1990), although probably less dramatic. Two lines of reasoning might explain this observation. First, the sizes of the largest ciliate and dinoflagellate dimensions in the $<20 \mu \mathrm{m}$ ESD size category were different. Dinoflagellates were (sub)spherical with diameters between $\sim 10$ and $\sim 17.5 \mu \mathrm{m}$, whereas ciliates typically were almost conical or elongated ellipsoids, with lengths of up to $30 \mu \mathrm{m}$, twice the diameter of an average-sized dinoflagellate. Thus, the actual size perceived by the copepods might have been larger for the ciliates in this size category, and dinoflagellates may have been close to the lower size limited of the particle spectra. Second, a faster swimming speed of ciliates may increase prey-predator encounter rates.
Even Myrionecta rubra was cleared efficiently by Calanus finmarchicus, although this ciliate has a pronounced escape behavior with burst swimming velocities reaching $8.5 \mathrm{~mm} \mathrm{~s}^{-1}$ elicited by an approaching copepod (Jonsson \& Tiselius 1990). Low clearance by Acartia tonsa when feeding on this ciliate was attributed to burst swimming, which equaled or exceeded the flow velocities generated by the copepod during feeding (Jonsson \& Tiselius 1990). It appears reasonable to assume that the much larger Calanus spp. create flow velocities sufficiently strong to capture $M$. rubra. Thus, although ciliates might have adapted to compensate for an increased predator encounter rate by an increased escape behavior, our results suggest that in the context of susceptibility to predators it may be a net disadvantage for heterotrophic protists to be fast swimmers.

\section{Ecological implications of a size-differentiated clearance}

A direct implication of the size-clearance relation is that large ciliates and dinoflagellates may experience a stronger top-down regulation than small species. Therefore, it is not only because of growth scale according to body size, with a negative exponent, that large ciliates are more strongly regulated than small ones as suggested by Nielsen \& Kiørboe (1994). More efficient predation on large ciliates presumably reinforces this pattern. A combination of size-selective feeding and low growth-rate of the larger species may explain why the size distribution of field ciliate and dinoflagellate communities usually are skewed towards smaller species (Fig. 10), and may reflect that top-down regulation is indeed very strong (Verity \& Smetacek 1996).

An indirect consequence of size-selective feeding is that regulation of heterotrophic protists by copepods potentially varies with depth. In the low chl a surface waters of stratified systems, a phytoplankton cell size, in the lower range of optimum copepod filtration efficiency, usually dominates. Relatively large heterotrophic protists are therefore more exposed to capture and consumption. Conversely, the subsurface water is often dominated by diatoms and heterotrophic protists of equal size, so the size discrepancy diminishes. Such a varying degree of regulation has previously been suggested partly to explain the elevated biomass patches of ciliates and heterotrophic dinoflagellates occurring concurrently with the spring bloom and subsurface peak of chain-forming diatoms (Nielsen \& Hansen 1995, Levinsen et al. 1999). A vertically-differentiated top-down regulation assumes an equal distribution of copepods in the water column. 


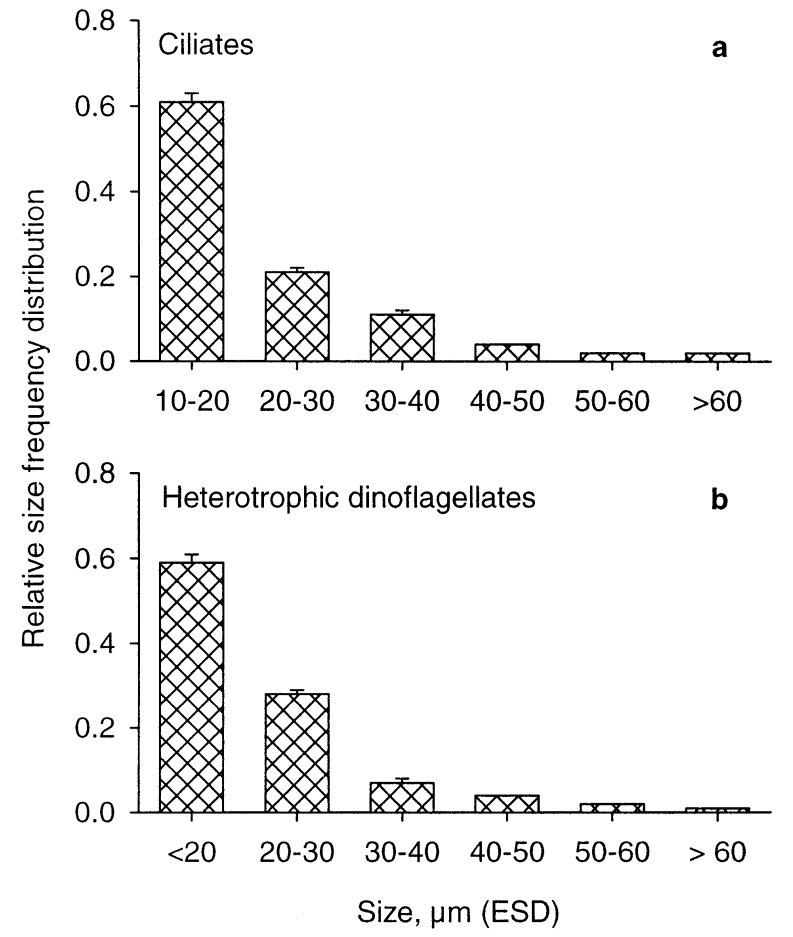

Fig. 10. Relative size distribution (mean \pm SE) of (a) ciliates and (b) heterotrophic dinoflagellates. Data from samples collected from the upper $15 \mathrm{~m}$ of the water column during an annual study conducted in Disko Bay, West Greenland, from April 1996 to June 1997 (Levinsen et al. 2000). n = 106

\section{Copepod body size and feeding activity}

Over the reported range of natural heterotrophic protist concentrations and size compositions we found a mean weight-specific Calanus clearance of $1{\mathrm{ml} \mathrm{ug}^{-1}}^{-1}$ $\mathrm{C} \mathrm{d}^{-1}$ at $3^{\circ} \mathrm{C}$ (range 0.1 to 2.2 ). This is very similar to a temperature corrected $C$. finmarchicus clearance on dinoflagellates and ciliates of 0.1 to $1.7 \mathrm{ml} \mathrm{\mu g}^{-1} \mathrm{C} \mathrm{d}^{-1}$ reported by Ohman \& Runge (1994). Our weightspecific clearance for the smaller C. finmarchicus on average exceeded that of the larger $C$. hyperboreus by $35 \%$. However, the maximum weight-specific clearance rate of the small-bodied Acartia longiremis was $\sim 4$ times higher than that of Calanus spp. Plotting maximum weight-specific clearance on ciliates as a function of adult female copepod weight (Fig. 11), including copepods of different body sizes from the literature, resulted in a log-log regression plot with a decreasing weight-specific clearance with body weight (scaling exponent -0.30). Thus, the maximum weight-specific clearance on ciliates by copepods, $F_{\max }$ $\left(\mathrm{ml} \mu \mathrm{g} \mathrm{C}^{-1} \mathrm{~d}^{-1}\right)$, is allometrically related to body size, $W\left(\mu \mathrm{g} \mathrm{C}\right.$ ind $\left.^{-1}\right)$, according to

$$
F_{\max }=a \times W^{0.30}
$$

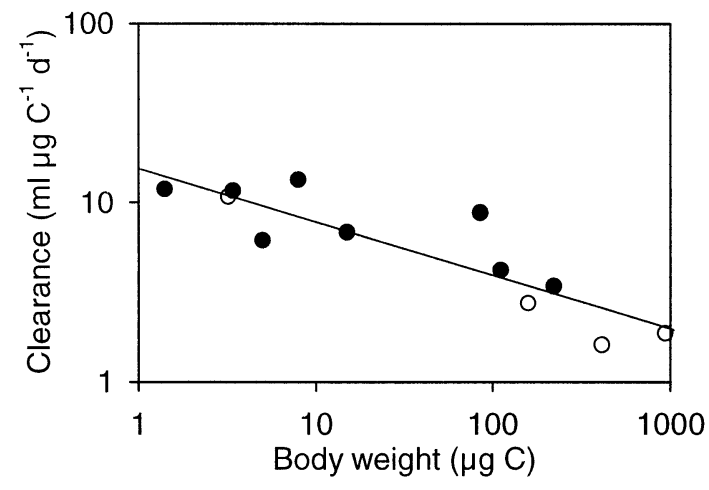

Fig. 11. Maximum weight-specific clearance at $5{ }^{\circ} \mathrm{C}$ by adult female copepods on natural ciliate populations scaled to the body weight for different-sized copepods collected from the literature (•): Acartia clausii, Centropages hamatus (Tiselius 1989); A. tonsa, Neocalanus plumchrus (Gifford \& Dagg 1991); Calanus finmarchicus (Ohman \& Runge 1994); Calanus pacificus, Centropages abdominalis, Pseudocalanus sp. (Fessenden \& Cowles 1994). A. longiremis, C. finmarchicus, C. glacialis and C. hyperboreus from this study are shown by open dots. A $Q_{10}$ of 2.8 was used to correct clearances to $5^{\circ} \mathrm{C}$. Coefficient of determination $\left(\mathrm{R}^{2}\right)$ for the regression line $=0.79$

where $a=15.8$. This indicates that small-bodied copepods like A. longiremis, and possibly also small developmental stages of Calanus spp. which dominate after the main bloom in the Arctic, have a great influence on the efficiency of the trophic coupling between the primary producers and the higher trophic levels.

Acknowledgements. We thank the crew on the RV 'Porsild' and 'Adolf Jensen' for their help at sea and the board of Arctic Station, Copenhagen University, for providing an excellent logistic platform for the cruises. Thanks to Thomas Kiørboe, Peter Verity and Per Juel Hansen for constructive criticism to an earlier version of this manuscript and to Birgit Søborg for technical assistance. This study was financially supported by The Danish National Research Council project no. 9501038 and 9700224 .

\section{LITERATURE CITED}

Andersen P (1988) The quantitative importance of the 'microbial loop' in the marine pelagic: a case study from the North Bering/Chukchi Sea. Arch Hydrobiol 31:243-251

Båmstedt U (1988) Ecological significance of individual variability in copepod bioenergetics. Hydrobiologia 167/ 168:43-59

Båmstedt U, Eilertsen HC, Tande KS, Slagstad D, Skjoldal HR (1992) Copepod grazing and its potential impact on the phytoplankton development in the Barents Sea. Polar Res 10:339-353

Barthel KG (1988) Feeding of three Calanus species on different phytoplankton assemblages in the Greenland Sea. Meeresforschung 32:92-106

Conover RJ, Huntley M (1991) Copepods in ice-covered seas - distribution, adaptations to seasonally limited food, 
metabolism, growth patterns and life cycle strategies in polar seas. J Mar Syst 2:1-41

Conover RJ, Harris LR, Bedo AW (1991) Copepods in cold oligotrophic waters-How do they cope? Proc 4th Int Conf on Copepoda. Bull Plankton Soc Jpn Spec 177-199

Fessenden L, Cowles TJ (1994) Copepod predation on phagotrophic ciliates in Oregon coastal waters. Mar Ecol Prog Ser 107:103-111

Frost BW (1972) Effects of size and concentration of food particles on the feeding behavior of the marine planktonic copepod Calanus pacificus. Limnol Oceanogr 17:805-815

Gifford DJ, Dagg MJ (1991) The microzooplankton-mesozooplankton link: consumption of planktonic protozoa by the calanoid copepods Acartia tonsa Dana and Neocalanus plumchrus Murukawa. Mar Microb Food Webs 5: 161-177

Hansen B, Verity P, Falkenhaug T, Tande KS, Norrbin F (1994) On the trophic fate of Phaeocystis pouchetti (Harriot). V. Trophic relationships between Phaeocystis and zooplankton: an assessment of methods and size dependence. J Plankton Res 16:487-511

Hansen BW, Nielsen TG, Levinsen H (1999) Plankton community structure and carbon cycling on the western coast of Greenland during the stratified summer situation. III. Mesozooplankton. Aquat Microb Ecol 16:233-249

Hansen PJ, Bjørnsen PK, Hansen BW (1997) Zooplankton grazing and growth: scaling within the $2-2,000-\mu \mathrm{m}$ body size range. Limnol Oceanogr 42:687-704

Huntley M (1981) Nonselective, nonsaturated feeding by three calanoid copepod species in the Labrador Sea. Limnol Oceanogr 26:831-842

Jespersen AM, Christoffersen K (1987) Measurements of chlorophyll-a from phytoplankton using ethanol as extraction solvent. Arch Hydrobiol 109:445-454

Jonsson P, Tiselius P (1990) Feeding behavior, prey detection and capture efficiency of the copepod Acartia tonsa feeding on planktonic ciliates. Mar Ecol Prog Ser 60:35-44

Kiørboe T (1998) Population regulation and role of mesozooplankton in shaping marine pelagic food webs. Hydrobiologia 363:13-27

Kiørboe T, Møhlenberg F, Hamburger K (1985) Bioenergetics of the planktonic copepod Acartia tonsa: relation between feeding, egg production and respiration, and composition of specific dynamic action. Mar Ecol Prog Ser 26:85-97

Levinsen H, Nielsen TG, Hansen BW (1999) Plankton community structure and carbon cycling on the western coast of Greenland during the stratified summer situation. II.

Editorial responsibility: Otto Kinne (Editor),

Oldendorf/Luhe, Germany
Heterotrophic dinoflagellates and ciliates. Aquat Microb Ecol 16:217-232

Levinsen H, Nielsen TG, Hansen BW (2000) The annual succession of marine pelagic protozoans in Disko Bay, West Greenland, with emphasis on winter dynamics. Mar Ecol Prog Ser (in press)

Nielsen TG, Hansen BW (1995) Plankton community structure and carbon cycling on the western coast of Greenland during and after the sedimentation of a diatom bloom. Mar Ecol Prog Ser 125:239-257

Nielsen TG, Hansen BW (1999) Plankton community structure and carbon cycling on the western coast of Greenland during the stratified summer situation. I. Hydrography, phytoplankton and bacterioplankton. Aquat Microb Ecol 16:205-216

Nielsen TG, Kiørboe T (1994) Regulation of zooplankton biomass and production in a temperate, coastal ecosystem. 2. Ciliates. Limnol Oceanogr 39:508-519

Nival P, Nival S (1976) Particle retention efficiencies of an herbivorous copepod, Acartia clausi (adult and copepodite stages): effects on grazing. Limnol Oceanogr 21:24-38

Norrbin MF, Olsen RE, Tande KS (1990) Seasonal variation in lipid class and fatty acid composition of two small copepods in Balsfjorden, northern Norway. Mar Biol 105: 205-211

Ohman MD, Runge JA (1994) Sustained fecundity when phytoplankton resources are in short supply: omnivory by Calanus finmarchicus in the Gulf of St. Lawrence. Limnol Oceanogr 39:21-36

Roman MR, Rublee PA (1980) Containment effects in copepod grazing experiments: a plea to end the black box approach. Limnol Oceanogr 25:982-990

Rysgaard S, Nielsen TG, Hansen BW (1999) Seasonal variations in nutrients, pelagic primary production and grazing in a high-Arctic coastal marine ecosystem, Young Sound, Northeast Greenland. Mar Ecol Prog Ser 179:13-25

Smetacek V (1981) The annual cycle of protozooplankton in the Kiel Bight. Mar Biol 63:1-11

Strathmann RR (1967) Estimating the organic carbon content of phytoplankton from cell volume or plasma volume. Limnol Oceanogr 12:411-418

Tiselius P (1989) Contribution of aloricate ciliates to the diet of Acartia clausi and Centropages hamatus in coastal waters. Mar Ecol Prog Ser 56:49-56

Verity PG, Smetacek V (1996) Organism life cycles, predation, and the structure of marine pelagic ecosystems. Mar Ecol Prog Ser 130:277-293

Submitted: December 29, 1999; Accepted: March 21, 2000 Proofs received from author(s): September 11, 2000 